\title{
The importance of cleaning in Islam and COVID-19 pandemic
}

\author{
Caksen $\mathrm{H}$ \\ Division of Behavioral-Developmental Pediatrics, Department of Pediatrics, Meram Medical Faculty, Necmettin Erbakan \\ University, Meram, Konya, Turkey. huseyincaksen@hotmail.com
}

Text in PDF www.elis.sk

To the editor:

Joachim Ernst Adolphe Felix Wach (1898-1955), German scholar and orientalist, speaking of the Holy Qur'an's importance to health, noted the following: "I would like to mention a phase of Islam that has not caught the attention of any European authors until now. This phase of Islam is its orders to keep the health. "Firstly, it is necessary to admit: The Holy Qur'an is superior to all the religious books. When we carefully consider simple but excellent sanitary rules described by the Holy Qur'an, thanks to this Holy Book, Asia the great crowd of insects and bugs, and some regions of the world are survived from such a significant threat. Obligating hygiene and cleanliness to Muslims, Islam has destroyed lots of devastating and destructive microbes” (1). Here, we have presented some hadiths mentioned by the Prophet Muhammad (SAW) and ayats in the Holy Qur'an about cleaning to highlight the importance of Islamic teachings in protecting against COVID-19 infection.

The Prophet Muhammad (SAW) said that cleanliness is half of faith (2). And your garments do purify. And uncleanness does shun. (The Holy Qur'an: Surah Al- Muddaththır, Chapter 74; Ayats 4 and 5). He will indeed be successful who purifies it (The Holy Qur'an: Surah Ash-Shams, Chapter 91; Ayat 9). The Prophet Muhammad (SAW) said: "Ten things are part of the Fitrah (It is the state of purity and innocence, all humans to be born with): Trimming the mustache, trimming the nails, washing the joints, letting the beard grow, using the Siwak, rinsing the nose, plucking the armpit hairs, shaving the pubes, and washing with water (after relieving oneself)." Mus'ab bin Shaibah said: "I have forgotten the tenth, unless it was rinsing the mouth.” (3). The Prophet Muhammad (SAW) said that wudu is effective body cleaning as well as in cleansing from sins at following hadith: "When a Muslim, or a believer, washes his face (in the course of wudu), every sin which he committed with his eyes, will be washed away from his face with water, or with the last drop of water; when he washes his hands, every sin which is committed by his hands will be effaced from his hands with the water, or with the last drop of water; and when he washes his feet, every sin his feet committed will be washed away with the water, or with the last drop of water; until he finally emerges cleansed of all his sins.” (4).

In conclusion, although more than a time of 1400 years has passed, the Holy Qur'an and hadiths preserve its freshness and youth, and they continue to provide solutions to people's problems. Therefore, we strongly believe that the cleaning rules in Islam are effective in preventing the spread of the COVID-19 infection that surrounds the whole world.

\section{References}

1. Nursi BS. From the Risale-i Nur Collection. İşaratü'l-İcaz. The testimonies of foreign philosophers regarding their approval of the Quran. [Internet]. Istanbul: Söz; 2012 [cited 2021 March 28]. http://www.erisale. com/\#content.tr.6.373.

2. Sahih Muslim 223; Book 2, Hadith 1 [cited 2021 March 28]. https:// sunnah.com/search?q=Cleanliness + is + half + the + faith

3. Sunan an-Nasa'i 5040; Book 48, Hadith 1 [cited 2021 March 28]. https://sunnah.com/nasai:5040

4. Riyad as-Salihin 1028; Book 8, Hadith 38 [cited 2021 March 28]. https://sunnah.com/riyadussalihin:1028 